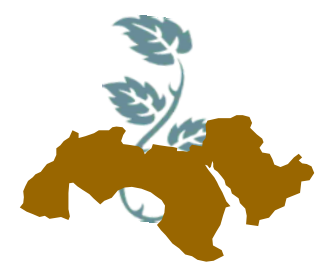

\title{
PRODUCING PROMISING PEA LINES THROUGH RE-SELECTION FOR YIELD AND QUALITY FROM MASTER B CULTIVAR
}

\author{
Wafaa S. Elsadek', S.M. Elminiawy ${ }^{2}$, S.A. Abd Elhady ${ }^{2}$ and A.A. Hamed \\ 1- Vegetable Research Dept., Horticulture Res. Inst., Agric. Res. Center, Giza, Egypt \\ 2- Horticultural Dept., Fac. Agric., Ain Shams Univ., Cairo, Egypt
}

Keywords: Pea, Pisum sativum. Selection, Genetic variability, Heritability, Genetic advance, Correlation, Growth traits, Pod yield, Seed yield

\section{ABSTRACT}

This investigation was conducted at Barrage Station (BHRS), Horticultural Research, Kalubia Governorate, Egypt, to get some new and promising pea lines (Pisum sativum L.) using pure line selection method on the basis of genetic variability. Selection was performed between or within four pea populations of Master B cultivar. The populations were collected from four different regions in Egypt and subjected to selection procedure during 2012/2013, 2013/2014 and 2014/2015 growing seasons. The investigation intended to study different traits of growth and yield and its components viz., No. of days to flowering, No. of first flowering node, plant length, No. of branches per plant, pod length, pod width, pod thickness, pod weight, No. of seeds per pod, weight of seeds per pod, No. of pods per plant, weight of 100 seeds, shelling percentage, pod yield per plant and seed yield per plant. The target of this study was to improve pea yield and its components as well as earliness of yielding. The analysis of variance revealed highly significant differences among genotypes for most of the studied characteristics, indicating ample scope of selection. Most characteristics showed a higher heritability coupled with higher genetic advance through two cycles of selection indicating that these characteristics are stable and can be improved through selection based on phenotypic observations. Twenty lines were obtained from selection program and were compared against the baseline populations in addition to check cultivar (Entsar1). Results showed significant differences among lines for most studied traits. Selection program resulted in genotypes or lines given symbols of H3, G7, N1, N3, G2, G1 and K2 that considered promising lines. These lines have good pods traits, higher productivity and earliness of flowering. Simple correlation coefficient analysis revealed that greater emphasis should be given to the traits of No. of branches and No. of pods per plant along with pod length, pod width, No. of seeds and weight of seeds per pod for yield improvement.

\section{INTRODUCTION}

Pea (Pisum sativum L.) is one of the important legume crops grown throughout the world. It has a high nutritional value as certain superior quality proteins like higher lysine content (Monti, 1983). Also shelled green seeds are rich in proteins, vitamins and minerals (Mohan et al 2013). In Egypt, pea is a winter season vegetable crop. The cultivated area reached 41957 feddans in 2014/2015 season, yielded 171533 tons of green pods with an average of 5.325 tons per feddan.

Master B cultivar is an old cultivar of garden pea and is well known in the Egyptian cultivation. It has been cultivated for more than 23 years ago because of its superior features. Otherwise, many reasons are behind the decline this cultivar and lacking of its certain good attributes. The reasons involve on wrong agricultural practices, wrong procedures of seed production, cultivar formation where it was produced at the beginning from some homogeneous pure lines had collected together. Climate changes consider the most important factor affecting cross-pollination percentage in selfpollinated plants. So, the natural out-crossing rate has been affected hypothetically and positively by 
pea genotype, increase ambient temperature during the flowering stage, insect pollinators visiting unopened pea flowers and pesticide treatments just before and during the flowering period (Dostálová et al 2005). These factors led to wastage of this good cultivar which became have a lot of variation of its attributes, therefore it became damaged.

The major challenges for Egyptian agriculture are loss of excellent old varieties as well as lack of improved varieties which possess high yielding and yield quality for achieve self-sufficiency and to face increasing human population. These challenges could be faced through breeding processes depend mainly on the presence of genetic variations which allow for an effective selection to obtain new lines, genetic improvement and perfect choice for the genotype installation. The superior pure line may use as a commercial variety therefore most the present varieties of self pollinated crops are pure lines.

Nosser (2011) and Bhnan (2013) used pedigree selection method for selection of some new lines of legumes and pea, respectively for high productivity and good pod characteristics, which is considered as new cultivars. Statistic significant differences among genotypes populations of garden pea indicated to presence of substantial amount of variation between the studied characteristics of genotypes in earlier researches carried out by Singh et al (2011), Kumar et al (2013a), Kumar et al (2013b), Pal and Singh (2013), Sharma and Bora (2013), Siddika et al (2013), Saxesena et al (2014), Ramzan et al (2014), Iqbal et al (2015), Kumar et al (2015) and Georgieva et al (2016). Hamed (2012) found that selection procedure led to increase pea traits means, i.e. number of days to flowering, green pod yield per plant, No. of pods per plant, No. of seeds per pod, average seed weight and pod length. Partitioning of total variability to its components which are heritable such as genotypic variance and non-heritable such as environmental variance is useful for knowing whether the superiority of selected traits is inherited by the progenies or not.

The large portion of phenotypic variance was due to the genetic variance in early segregating generations in garden pea (Hamed, 2012). Singh et al (1997) proceeded genetic analysis to estimate components of genetic variance. Significant estimates of both additive and dominance components were observed for all the traits, except for pod length. The direction of dominance was positive and significant for days to flowering, plant height, number of pods per plant and seed yield indicating the isodirectional nature of dominance. Amin et al (2010) stated that the highly heritable polygenic characters are plant height, earliness, number of pods per plant, pod length, number of seeds per pod and 100 seed weight but pod yield has low heritability. The worth to be mentioned that number of branches, earliness, number of pods per inflorescence, number of pods per plant, number of seeds per plant, seed weight and number of days to maturity and plant height had direct effect on yield. As shown by Habtamu and Million (2013), the estimated values of phenotypic variances were small in trait of No. of days to flowering but high in trait of seed yield. The highest genotypic variances were found for trait of seed yield. Otherwise the phenotypic variance was higher than genotypic variance in all studied characteristics as reported by Siddika et al (2013). The highest phenotypic variance was recorded in seed yield. Meanwhile, genotypic variance value was the highest in 1000 seed weight followed by seed yield and plant height, indicating the greater magnitude of genetic variability for these traits. Higher environmental variance values of seed yield and plant height indicated that both seed yield and plant height were highly influenced by environment, but other traits were less influenced by environment (Georgieva et al 2016).

Wide differences between phenotypic coefficient of variation (PCV) and genotypic coefficient of variation (GCV) were found in traits of shelling percentage, No. of pods per plant, node at which first flower appears and pod yield per plant. This indicates that these traits had affected slightly more by environment (Sharma et al 2011). Low estimated values of PCV and GCV of days to $50 \%$ flowering attribute suggesting small role for environment in the expression of these characteristics (Basaiwala et al 2013; Kumar et al 2013a). Otherwise, higher values of PCV and GCV were observed for plant height, No. of pods per plants, pod length, No. of seeds per pod, 100-seed weight and seed yield per plant (Kumar et al 2013b). The higher values of PCV and GCV were recorded for the characteristics plant height, No. of pods per plant, green pod yield and No. of primary branches per plant, indicating the substantial amount of environmental effect in the expression of the traits and indicating high level of variation which provide ample scope for effective improvement (Pal and Singh, 2013). Also high PCV as well as GCV values were observed for pod yield per plant (Pandey et al 2015). The GCV simply measures the extent 
of genetic variations present for certain characteristics and it alone is not sufficient for determine the heritable variability. Thence, the heritability gives only an idea about the proportion of total variability that is due to genetic causes. Hence GCV together with heritability estimates would give the best picture of the advance to be expected by selection (Chadha et al 2008; Kumari et al 2012 and Kumar et al 2015). High heritability was observed for all the studied traits and the highest value was recorded by grain number per pod which was about $98.15 \%$ (Chadha et al 2008). The results revealed high estimates of $\mathrm{BSH} \%$ (above 60\%) were observed for plant height (95.00), days to $50 \%$ flowering (95.00), yield per plant (88.00), pod length (72.00), 100 seed weight (70.00), No. of seeds per pod (69.00) and No. of pods per plant (62.00) (Saxesena et al 2014). Heritability estimate as $\mathrm{BSH} \%$ provides guide for the breeder to be followed through selection procedures for improvement of these traits. But, when calculate estimated heritability and genetic advance together provide more useful results for predicting the effect of selection procedure which is done depending on phenotypic expression and expected genetic advance as percent of mean indicates the mode of gene action in the expression of different characteristics (Kumar et al 2013a and Sharma \& Bora, 2013). High genetic advance along with high heritability were observed for the characteristics of days to $50 \%$ flowering, plant height, No. of branches per plant, pod length, pod width, No. of seeds per pod, No. of pods per plant, 100 seed weight, pod yield per plant and seed yield per plant in earlier works had carried out by Chaudhary and Sharma (2003), Singh and Singh (2006), Gupta et al (2006), Sharma et al (2011), Tyagi et al (2012), Kumar et al (2013a), Kumar et al (2013b), Pal \& Singh (2013), Sharma \& Bora (2013), Siddika et al (2013) and Georgieva et al (2016). Study of plant characteristics associated with yield characteristic and associated among them are highly useful for plant breeders to get improvement through selection program depends on the proportionality between different characteristics for selection. Selection for any characteristic may affected positively or negatively by the related characteristics.

The yield is controlled by numerous genes, so all genes control yield components characteristics are responsible for yield, therefore the direct selection for yield may not be effective if selection is based mainly on yield alone considering it as a simple characteristic. It is apparent that seed yield in field pea can be improved by selection such genotype has greater No. of pods per plant (Singh et al 2011; Basaiwala et al 2013; Kumar et al 2013a; Siddika et al 2013 and Ramzan et al 2014). Genotypes with the greater No. of pods per plant should be given an emphasis for improving pod yield and the desired improvement could be achieved through the recurrent selection procedure (Sharma et al 2011 and Kumar et al 2015). Green pod yield per plant showed positive and significant genotypic correlation with pod length (Singh and Lokendra, 2015). Pod yield showed a positive and significant correlation with No. of pods per plant and pod length (Katoch et al 2016).

The pure line selection procedure, within four populations of Master B cultivar, has been used in the present work in order to make use of the existing variation which appears in all characteristics for cultivar improvement. The aim of this work was to achieve two main goals. First goal is to obtain high yielding lines which could be used as new promising cultivars. Second goal is to obtain new lines with good characteristics that could be used as parents for further breeding programs for improving agronomic performance and pod yield and quality. That is through studying genetic variability, broad sense heritability, estimating the genetic advance and its estimate as a percentage of mean through two cycles of selection were done besides determination of the correlation existed among the various characteristics. Such study may help in developing yield and quality of pea.

\section{MATERIAL AND METHODS}

The experiment was carried out at Barrage Horticultural Research Station (BHRS), Kalubia Governorate, Egypt during the winter seasons of 2012/2013, 2013/2014 and 2014/2015.

\section{Plant materials and experimental design}

Four populations of pea cultivar of Master B were collected from four different regions of Kaha (EL-Kalubia Governorate), Nubaria (EL-Beheira Governorate), Gharbia (EL-Garbia Governorate) and Horticulture (Horticulture Research Institute Ministry of Agriculture, Cairo, Egypt). The experiment was established in a complete randomized block design with three replications. Each replicate has sown randomly by seeds of all the populations. Pure line selection method was applied as follows:

During the winter season of 2012 /2013, the four populations seeds were sown at a rate of about 1000 plants per each population and were 
evaluated as base populations. Observations were recorded on thirty marked plants from each replication for each population. Selection procedure was performed inside each of the four populations for best vegetative growth, pod yield and quality characteristics, viz., earliness of yielding, length of plant and number of pods per plant as well as pod quality characteristics. The progenies of forty seven individual plants which have been selected from the four populations as described in Table (1) through first selection cycle were sown and evaluated during winter season of 2013/2014. For study the attributes of each progeny, data were recorded on a random 15 plants from each progeny. Second selection cycle was carried out during 2013/2014 winter season and resulted in 20 featured plants. Through winter season of $2014 / 2015$, the progenies of the twenty selected individual plants were sown and evaluated comparing with the bulk populations and check cultivar "Entsar1". Data were collected on a sample of 40 plants represented each progeny or selected line.

Table 1. Selection intensity with names, numbers and source of the selected lines

\begin{tabular}{|c|c|c|c|c|c|}
\hline \multirow{2}{*}{$\begin{array}{c}\text { Source (bulk } \\
\text { population) }\end{array}$} & \multicolumn{2}{|c|}{$\begin{array}{c}\text { Selection } \\
\text { intensity }\end{array}$} & \multicolumn{2}{|c|}{$\begin{array}{c}\text { No. of selected } \\
\text { plants }\end{array}$} & \multicolumn{1}{|c|}{$\begin{array}{c}\text { The selected } \\
\text { lines }\end{array}$} \\
\cline { 2 - 5 } & $\begin{array}{c}\text { First } \\
\text { cycle }\end{array}$ & $\begin{array}{c}\text { Se- } \\
\text { cond } \\
\text { cycle }\end{array}$ & $\begin{array}{c}\text { First } \\
\text { cycle }\end{array}$ & $\begin{array}{c}\text { Second } \\
\text { cycle }\end{array}$ & \\
\hline Kaha (kB) & $15 \%$ & $2 \%$ & 14 & 4 & K1- K2-K3-K4 \\
Nubaria (NB) & $10 \%$ & $2 \%$ & 9 & 3 & $\begin{array}{l}\text { N1-N2- N3 } \\
\text { G1- G2- G3- }\end{array}$ \\
$\begin{array}{c}\text { Gharbia (GB) } \\
\text { Horticulture } \\
\text { (HB) }\end{array}$ & $15 \%$ & $5 \%$ & 14 & 7 & $\begin{array}{l}\text { G4- G5- G6-G7 } \\
\text { H1- H2 - H3 - } \\
\text { H4 - H5 - H6 }\end{array}$ \\
\hline
\end{tabular}

In the three seasons, sowing dates were in the $2^{\text {nd }}$ week of November, then the procedures of selection were conducted and the observations were recorded. The superior plants were individually selected, marked and evaluated. The seeds of each selected plant were collected and saved. Some of seeds were collected randomly from the remaining plants of each population to give the bulk seeds for next season. The seeds of individual plants were sown in 3.5 meter rows, and plants were spaced $10 \mathrm{~cm}$ apart within the rows. The cultural practices, i.e. irrigation, fertilization and pest control, were applied as recommended according to the recommendations of Ministry of Agriculture for the cultivation area.

\section{Data recorded}

1- Growth characteristics: plant length, No. of branches per plant, No. of days to flowering and No. of first flowering node.

2- Yield and its components: No. of pods per plant, pod length, pod width, pod thickness, pod weight, No. of seeds per pod, weight of seeds per pod, weight of 100 seeds $=($ weight of seeds per pod / No. of seeds per pod) $X$ 100 , shelling percentage $=$ (grain weight $/$ pod weight) $X 100$, pod yield per plant $=($ No. of pods per plant $X$ pod weight) and seed yield per plant $=$ (weight of seeds per pod $X$ No. of pods per plant).

\section{Statistical and genetic analyses}

Analysis of variance was carried out according to Sendecor and Cochran (1982).

Mean values were compared by the Duncan's multiple range test (Duncan, 1955).

The phenotypic and genotypic variances were estimated according to the method suggested by Burton and DeVane (1953).

The coefficient of variations at phenotypic (PCV\%) and genotypic (GCV\%) level variation was calculated as the method suggested by Johnson et al (1955).

Estimates of heritability in a broad sense (BSH\%), genetic advance (GA) and genetic advance as percent of mean (GA\%) were computed using the formula adopted by Allard (1960).

Simple correlation coefficients were calculated by depending on using the formula given by Singh and Chaudhary (1985).

The data were statistically analyzed using SAS (2006) software.

In order to facilitate the description of different estimated parameters: The estimates of GCV and PCV were classified as low, medium and high by limits used by Kumar et al (2013b). The high heritability is above $60 \%$ was adopted by Basaiwala et al (2013), Kumar et al (2013a), Kumar et al (2013b) and Saxesena et al (2014) and they used similar limits to describe the results. Also, genetic advance was classified by adopting the limits used by Kumar et al (2013a) and Kumar et al (2013b). The limits used for categorizing the magnitude of different parameters under this study are as follows: 
Table 2. Limits used for categorizing the magnitude of different parameters.

\begin{tabular}{|c|c|c|c|}
\hline Component & Low (\%) & $\begin{array}{l}\text { Moder- } \\
\text { ate }(\%)\end{array}$ & High (\%) \\
\hline PCV and GCV & $\begin{array}{c}\text { Less than } \\
10 \%\end{array}$ & $10-25 \%$ & $\begin{array}{c}\text { More than } \\
25 \%\end{array}$ \\
\hline Heritability & $\begin{array}{c}\text { Less than } \\
40 \%\end{array}$ & $40-60 \%$ & $\begin{array}{c}\text { More than } \\
60 \%\end{array}$ \\
\hline Genetic advance & $\begin{array}{c}\text { Less than } \\
10 \%\end{array}$ & $10-20 \%$ & $\begin{array}{c}\text { More than } \\
20 \%\end{array}$ \\
\hline
\end{tabular}

\section{RESULTS AND DISCUSSION}

\section{Evaluation of the baseline populations}

The magnitude of genetic variation existing in the base populations of the crop is pivotal to its improvement. Although pod yield and seed yield of certain crop are considered the ultimate goal of the breeder but these traits are the result of interaction of many other traits which influence them in direct or indirect way. To obtain a maximum gain in pod and seed yield variability existing within each component trait must be exploited by the breeder. Data in Table (3) revealed a wide range of variation between the individual plants within populations for all studied characteristics. Also the mean sum of squares due to genotypes exhibited significant differences for most of the characteristics under study, except No. of branches per plant, pod yield per plant and seed yield per plant. This indicates a substantial amount of variability between the studied genotypes for almost all the characteristics. These characteristics constitute together the yield (Amin et al 2010). The non significant variability in No. of branches per plant was shown by Siddika et al (2013) and Ramzan et al (2014) as well as in seed yield (Georgieva et al 2016).

Table 3. Range and mean squares for studied traits in baseline populations of garden pea

\begin{tabular}{|c|c|c|c|c|}
\hline \multirow[t]{2}{*}{ Studied traits } & \multicolumn{2}{|c|}{ Range of the trait } & \multirow{2}{*}{$\begin{array}{c}\begin{array}{c}\text { Mean squares due to } \\
\text { genotypes }\end{array} \\
\mathrm{df}=3 \\
\end{array}$} & \multirow[t]{2}{*}{$F$ value } \\
\hline & Minimum & Maximum & & \\
\hline Plant length (cm) & 32 & 145 & 6462.85 & $15.6^{\star *}$ \\
\hline No. of branches/plant & 1 & 5 & 0.74 & 2.41 \\
\hline No. of days to flowering & 44 & 64 & 166.60 & $15.94^{\star *}$ \\
\hline $\begin{array}{l}\text { No. of first flowering } \\
\text { node }\end{array}$ & 5 & 15 & 6.05 & $2.58^{\star}$ \\
\hline Pod length (cm) & 6.1 & 14.4 & 41.06 & $26.07^{\star *}$ \\
\hline Pod width (cm) & 0.6 & 1.91 & 0.36 & $11.97^{\star \star}$ \\
\hline Pod thickness (cm) & 0.52 & 1.4 & 0.21 & $10.42^{\star *}$ \\
\hline Pod weight (g) & 2.4 & 11.4 & 46.16 & $16.21^{* *}$ \\
\hline No. of seeds/pod & 3 & 11 & 18.83 & $8.86^{\star *}$ \\
\hline Weight of seeds/pod (g) & 0.7 & 5.7 & 3.28 & $4.8^{* *}$ \\
\hline No. of pods/plant & 2 & 42 & 269.50 & $7.46^{\star \star}$ \\
\hline Weight of 100 seeds (g) & 11 & 70 & 366.80 & $3.8^{*}$ \\
\hline Shelling percentage (\%) & 10.53 & 80 & 476.40 & $6.16^{\star *}$ \\
\hline Pod yield/plant (g) & 8.6 & 284.8 & 1686.88 & 1.08 \\
\hline Seed yield/ plant (g) & 2.6 & 121.6 & 592.92 & 1.78 \\
\hline
\end{tabular}

${ }^{*}$ and ${ }^{* *}$ Significant at .05 and .01 probability levels, respectively. 


\section{Genetic parameters through two cycles of se- lection}

\section{General mean of selected families}

Data in Tables (4) and (5) display genetic parameters of the baseline four populations of pea through first and second selection cycles, respectively. Data revealed improvement of general mean of most of plant characteristics during the second selection cycle comparing to the first selection cycle. however general mean of No. of first flowering node, No. of branches per plant, pod length and pod width showed a slight decrease within second selection cycle compared to the first selection cycle. Therefore continue selecting procedure may result in pure breeded lines having valuable traits. These pure breeded lines could be used as parents for further breeding programs for improving agronomic performance, pod yield and quality. Furthermore, the differences between the obtained pure lines properties in growth characteristics, pod yield and quality could make them use as new promising cultivars especially the featured ones, as mentioned before by Nosser (2011) and Bhnan (2013). These results revealed that general mean of the traits reflects the effective role of selection and partially agree with findings of Hamed (2012).

Estimation of phenotypic, genotypic and environmental variances

Through the two selection cycles, data in Tables (4) and (5) showed that except shelling percentage trait, the estimated values of phenotypic variance of all traits were higher than their respective genotypic variance (heritable portion). Moreover, the estimates of genetic variances were higher than those of environmental variances (nonheritable) in addition to fewer differences between phenotypic and genetic variance. Therefore, the large portion of the phenotypic variance was due to the genetic variance so that selection can improve these crop traits. In this regard, germplasm genetic diversity determines the framework of selection in crop improvement. Furthermore, knowledge of genetic relations among agronomic traits is regarded to support considerable help to maintain genetic improvement to breeding program. Crop improvement with heritable characters, estimation of genetic parameters and their relations are of prime importance in breeding (Ajmal et al 2009; Bozokalfa et al 2011 and Esiyok et al 2011).

Table 4. Genetic parameters for different characteristics in the first cycle of selection in pea

\begin{tabular}{|c|c|c|c|c|c|c|c|c|c|c|c|}
\hline Studied traits & Mean & $\sigma^{2} p$ & $\sigma^{2} g$ & $\sigma^{2} e$ & PCV \% & GCV \% & ECV\% & G.C.V/ P.C.V & BSH $\%$ & GA & GA \% \\
\hline Plant length (cm) & 69.07 & 1853.65 & 1667.46 & 186.19 & 58.87 & 55.03 & 19.76 & 0.92 & 84.45 & 59.66 & 86.07 \\
\hline No. of branches/plant & 1.87 & 3.30 & 2.39 & 0.90 & 96.46 & 80.17 & 50.33 & 0.80 & 65.97 & 2.01 & 109.84 \\
\hline No. of days to flowering & 44.29 & 25.89 & 22.78 & 3.12 & 11.13 & 10.40 & 3.92 & 0.93 & 86.86 & 7.21 & 16.27 \\
\hline No. of first flowering node & 8.55 & 16.95 & 15.09 & 1.86 & 46.80 & 43.70 & 15.94 & 0.92 & 85.67 & 5.86 & 68.14 \\
\hline Pod length (cm) & 9.66 & 8.26 & 7.15 & 1.10 & 28.91 & 26.55 & 10.87 & 0.91 & 83.07 & 3.95 & 40.67 \\
\hline Pod width (cm) & 1.30 & 0.16 & 0.11 & 0.05 & 30.40 & 25.12 & 16.77 & 0.82 & 67.72 & 0.45 & 34.55 \\
\hline Pod thickness (cm) & 0.84 & 0.10 & 0.07 & 0.03 & 38.24 & 31.12 & 21.61 & 0.81 & 66.62 & 0.35 & 41.86 \\
\hline Pod weight (g) & 6.15 & 8.66 & 5.65 & 3.01 & 47.64 & 37.34 & 28.17 & 0.76 & 59.07 & 2.98 & 49.39 \\
\hline No. of seeds/pod & 7.64 & 5.01 & 3.35 & 1.66 & 29.19 & 23.73 & 16.88 & 0.81 & 66.00 & 2.44 & 31.82 \\
\hline Weight of seeds/pod (g) & 2.17 & 2.04 & 1.36 & 0.69 & 66.98 & 53.79 & 38.13 & 0.78 & 61.91 & 1.50 & 72.22 \\
\hline No. of pods/plant & 9.67 & 60.11 & 42.42 & 17.69 & 79.85 & 66.52 & 43.57 & 0.83 & 68.32 & 8.90 & 93.20 \\
\hline Weight of 100 seeds (g) & 28.60 & 260.24 & 150.46 & 109.77 & 56.61 & 41.99 & 36.57 & 0.72 & 52.58 & 14.29 & 52.06 \\
\hline Shelling percentage (\%) & 36.26 & 292.67 & 101.29 & 191.37 & 47.17 & 27.73 & 37.81 & 0.59 & 35.37 & 9.85 & 27.46 \\
\hline Pod yield/plant (g) & 59.13 & 2645.14 & 1641.25 & 1003.89 & 86.17 & 67.00 & 53.54 & 0.77 & 59.51 & 51.98 & 88.04 \\
\hline Seed yield/ plant $(g)$ & 20.58 & 353.50 & 208.05 & 145.45 & 91.17 & 69.78 & 58.56 & 0.76 & 58.33 & 18.26 & 89.02 \\
\hline
\end{tabular}

Data presented in the table are the average values of the studied four populations.

$\sigma^{2} p, \sigma^{2} g$ and $\sigma^{2} e$ : phenotypic, genotypic and environmental variances.

PCV \%, GCV \%, ECV \% and G.C.V/P.C.V: phenotypic, genotypic, environmental coefficients of variation and G.C.V/ P.C.V ratio. $\mathrm{BSH} \%, \mathrm{GA}$ and GA \%: Broad sense heritability, Genetic advance and Genetic advance as a percent of mean. 

Master B Cultivar

Table 5. Genetic parameters for different characteristics in the second cycle of selection in pea

\begin{tabular}{|c|cccccccccccc|}
\hline Studied traits & Mean & $\sigma^{2} \mathbf{p}$ & $\sigma^{2} \mathbf{g}$ & $\sigma^{2} \mathbf{e}$ & PCV \% & GCV \% ECV\% G.C.V/ P.C.V BSH\% & GA & GA \% \\
\hline Plant length (cm) & 52.04 & 2029.75 & 1893.15 & 136.60 & 69.27 & 64.12 & 22.12 & 0.87 & 77.46 & 75.11 & 136.31 \\
No. of branches/plant & 1.75 & 5.83 & 4.84 & 0.99 & 133.83 & 120.79 & 56.43 & 0.90 & 80.65 & 4.24 & 242.48 \\
No. of days to flowering & 39.22 & 66.07 & 64.99 & 1.08 & 20.11 & 19.90 & 2.14 & 0.99 & 97.55 & 17.57 & 44.87 \\
No. of first flowering node & 9.08 & 4.23 & 2.63 & 1.60 & 22.09 & 16.56 & 13.94 & 0.72 & 54.47 & 2.62 & 28.51 \\
Pod length (cm) & 9.29 & 20.98 & 20.36 & 0.62 & 46.11 & 44.87 & 8.34 & 0.94 & 89.15 & 9.19 & 101.36 \\
Pod width (cm) & 1.26 & 0.15 & 0.14 & 0.01 & 29.15 & 27.35 & 9.67 & 0.93 & 85.81 & 0.73 & 57.63 \\
Pod thickness (cm) & 0.99 & 0.07 & 0.06 & 0.01 & 24.53 & 22.58 & 8.87 & 0.90 & 81.15 & 0.48 & 47.69 \\
Pod weight (g) & 6.18 & 14.91 & 13.01 & 1.90 & 60.73 & 55.86 & 22.26 & 0.90 & 81.23 & 7.11 & 117.01 \\
No. of seeds/pod & 7.94 & 11.22 & 9.48 & 1.74 & 38.69 & 33.31 & 16.47 & 0.79 & 66.52 & 5.40 & 69.00 \\
Weight of seeds/pod (g) & 2.82 & 4.17 & 3.49 & 0.67 & 71.33 & 64.73 & 29.10 & 0.90 & 81.04 & 3.79 & 134.49 \\
No. of pods/plant & 11.07 & 655.49 & 587.51 & 67.99 & 215.04 & 198.65 & 74.63 & 0.90 & 82.13 & 46.72 & 416.44 \\
Weight of 100 seeds (g) & 35.75 & 530.93 & 448.27 & 82.66 & 59.96 & 53.47 & 25.45 & 0.87 & 76.25 & 39.46 & 108.93 \\
Shelling percentage (\%) & 46.88 & 373.41 & 174.33 & 199.08 & 40.24 & 25.71 & 30.01 & 0.61 & 39.21 & 18.24 & 38.73 \\
Pod yield/plant (g) & 68.49 & 24373.02 & 21216.18 & 3156.84 & 209.56 & 187.11 & 81.68 & 0.84 & 73.63 & 267.38 & 378.17 \\
Seed yield/ plant (g) & 31.02 & 4762.71 & 4047.98 & 714.73 & 200.34 & 170.48 & 84.50 & 0.73 & 65.54 & 112.31 & 346.01 \\
\hline
\end{tabular}

Data presented in the table are the average values of the studied four populations.

$\sigma^{2} p, \sigma^{2} g$ and $\sigma^{2} e$ : phenotypic, genotypic and environmental variances.

PCV \%, GCV \%, ECV \% and G.C.V/ P.C.V: phenotypic, genotypic, environmental coefficients of variation and G.C.V/ P.C.V ratio. $\mathrm{BSH} \%, \mathrm{GA}$ and GA \%: Broad sense heritability, Genetic advance and Genetic advance as a percent of mean.

The phenotypic variance values were highest for plant length (1853.65, 2029.75), pod yield per plant $(2645.14,24373.02)$ and seed yield per plant (353.50, 4762.71) but lowest value was recorded for pod thickness $(0.10,0.07)$ in the first and second selection cycles, respectively. Genotypic variance was higher for plant length (1667.46, 1893.15), pod yield per plant $(1641.25,21216.18)$ and seed yield per plant $(208.05,4047.98)$, in first and second selection cycles, respectively, consequently the greater magnitude of genetic variability for these traits. Higher environmental variance was showed for the plant length $(186.19,136.60)$, pod yield per plant $(1003.89,3156.84)$ and seed yield per plant $(145.45,714.73)$ in first and second selection cycles, respectively. While the minimum environmental variance value (0.03 and 0.01$)$ was obtained in pod thickness through the two selection cycles, respectively. These results agree with those found by Hamed (2012), Habtamu and Million (2013), Siddika et al (2013) and Georgieva et al (2016). Concerning shelling percentage which recorded genetic variance value less than environmental variance indicate that environment had large portion of its phenotypic variance. These results were confirmed by suggestions of Sharma et al (2011) by obvious influence of the environ- ment on shilling percentage. Meanwhile, disagree with results of Katoch et al (2016) who reported that the differences between the genotypic and phenotypic variances were relatively low for all traits including shelling percentage.

\section{Estimation of variation coefficient of pheno- type, genotype and environment}

The comparison between crop traits with regard to the extent of genetic variation could be better decided by the estimation of genotypic coefficient of variation (GCV) in relation to their respective phenotypic coefficient of variation (PCV) (Chakraborty and Chakraborty, 2010).Through the two selection cycles, the displayed data in Tables (4) and (5) showed that PCV values were higher than GCV values for all studied traits. Otherwise, the values of GCV were higher than those of ECV, for most traits except shelling percentage. Number of days to flowering exhibited moderate values of PCV $(11.13 \%, 20.11 \%)$ and GCV $(10.40 \%, 19.90 \%)$ for first and second cycle of selection, respectively. As well as the lower values of $\operatorname{ECV}(3.92 \%, 2.14 \%)$ and higher values of GCV / PCV ratio $(0.93,0.99)$ for two consecutive cycles of selection indicating the large role of genetics for 
governing these characteristics but negligible influence of environment on its expression. These results of No. of days to flowering are in agreement with those of Basaiwala et al (2013) and Kumar et al (2013a). Values of PCV, GCV and ECV for the other characteristics were supreme. The highest values were recorded in No. of branches per plant, No. of pods per plant, pod yield per plant and seed yield per plant. This refers that the environment has influenced the expression of these traits. But the large role of genetic portion for governing these characteristics is proved by raising the estimates of GCV / PCV ratio for all these characteristics within the two cycles of selection. Increasing PCV and GCV coefficients of variability in the second selection cycle reflect the differential response to selection and indicate that there is a sufficient genetic variation after two cycles of selection for further improvement in these populations and the sensitivity of the gene pools to environmental effects. These results are in accordance with those found by Sharma et al (2011), Kumar et al (2013b), Pal \& Singh (2013) and Pandey et al (2015).

Regarding shelling percentage within the consecutive two selection cycles, the estimated values of $\operatorname{GCV}(27.73 \%, 25.71 \%)$ were less than those of ECV $(37.81 \%, 30.01 \%)$. Also minimal estimate value of GCV / PCV ratio (0.59 - 0.61) indicate that shelling percentage is influenced strongly by the environment. When the environmental variance is greater than the genetic variance this indicates that the trait would be polygenic trait (Georgieva et al 2016). These results disagree with the result of Sharma and Bora (2013) who found that the GCV was higher than the ECV for this character.

\section{Estimation of heritability in a broad sense (BSH} $\%)$

The heritable variation with heritability (broad sense) estimates would give or serve as reliable indication of expected improvement through selection program (Johnson et al 1955). Data in Tables (4) and (5) revealed that No. of days to flowering exhibited the highest value of heritability $(86.86 \%$, $97.55 \%)$ but the shelling percentage exhibited the lowest value of heritability $(35.37 \%, 39.21 \%)$ for the two consecutive selection cycles. Heritability estimate in earlier researches recorded higher value for trait of days to $50 \%$ flowering as mentioned by Kumar et al (2013a). While the heritability estimate value for shelling percentage trait recorded $27.91 \%, 49.25 \%$ and $78.38 \%$ as mentioned by
Kumari et al (2012), Sharma et al (2011) and Sharma and Bora (2013), respectively. High estimate value of heritability ( $>60 \%$ ) was exhibited for characteristics of. plant length, No. of branches per plant, pod length, pod width, pod thickness, No. of seeds per pod, weight of seeds per pod and No. of pods per plant in addition to No. of days to flowering in the two consecutive selection cycles. Thence, these characteristics serve as a useful and effective guide to the plant breeders. Therefore, the improvement will be occurred through selection procedure based on these traits. These results are in agreement with earlier findings by Chadha et al (2008) and Saxesena et al (2014).

The estimated heritability recorded moderate to high values for the characteristics No. of first flowering node $(85.67 \%, 54.47 \%)$, pod weight $(59.07 \%, 81.23 \%)$, weight of 100 seeds $(52.58 \%$, $76.25 \%)$, pod yield per plant $(59.51 \%, 73.63 \%)$ and seed yield per plant $(58.33 \%, 65.54 \%)$ through the two selection cycles, respectively. Sharma and Bora (2013) reported that heritability estimate provides guide for the selection procedure to be followed by the breeders for improvement of these traits under a given environment. For the characteristic of hundred seeds weight, the results are in consistent with those of Singh et al (2011) who proved that heritability values of these characteristics are moderately high. Also Basaiwala et al (2013) reported moderate heritability for the same characteristic.

\section{Estimation of expected genetic advance}

Data in Tables (4) and (5) indicate that the expected genetic advance as percentage of estimated means of traits had ranged between $16.27 \%$ in No. of days to flowering to $109.84 \%$ in No. of branches per plant for the first cycle of selection. This indicating high genetic advance (>20\%) for all studied characteristics except No. of days to flowering which recorded moderate genetic advance (10\%-20\%). As for genetic advance within second selection cycle, all traits achieved genetic advance percent above moderate limits. Thence, the expected genetic advance percentage values were ranged between $28.51 \%$ in No. of first flowering node to $416.44 \%$ in No. of pods per plant. Therefore, in the second cycle of selection, all characteristics except No. of first flowering node and shilling percentage, the high estimates of heritability coupled with high expected genetic advance as percentage of mean besides high values of GCV which confer ample scope of selection for further 
improvement especially for No. of pods per plant, pod yield and seed yield. These results are in agreement with findings by Chaudhary and Sharma (2003), Singh and Singh (2006), Gupta et al (2006), Tyagi et al (2012), Kumar et al (2013a), Pal and Singh (2013), Sharma and Bora (2013), Kumar et al (2013b), Siddika et al (2013) and Georgieva et al (2016).

Kumari et al (2012) reported that selection may not be rewarding for shelling percentage and No. of first fruiting node, therefore other breeding methods should be taken for improvement of these traits. Higher heritability along with moderate genetic gain for nodes to first flower was indicating a preponderance of additive effect. This suggests that the selection might be effective in the further improvement of this trait (Kumari et al 2008). The obtained results confirmed that the characteristics which possessing higher GCV, higher heritability and genetic advance could be effectively used in selection as it had been suggested by Johnson et al (1955) who reported that characteristics with higher heritability coupled with higher genetic advance would response to selection better than those with higher heritability and lower genetic advance.

The characteristics which exhibited higher heritability coupled with higher genetic advance for the two consecutive cycles of selection were plant length, No. of branches per plant, pod length, pod width, pod thickness, No. of seeds per pod, weight of seeds per pod and No. of pods per plant.

This suggesting the potential improvement in pea yield would be achieved through selection for these characteristics and indicating role of additive gene action in the expression of these traits. Most of these results are in agreement with those reported by Chaudhary and Sharma (2003), Singh and Singh (2006), Gupta et al (2006), Sharma et al (2011), Tyagi et al (2012), Kumar et al (2013a), Kumar et al (2013b), Pal and Singh (2013), Sharma and Bora (2013), Siddika et al (2013) and Georgieva et al (2016).

\section{Assessment of selected lines}

Analysis of variance was measured to determine the degree of variability between the obtained materials from selection program. The materials are consisted of twenty selected lines which were selected from the four baseline populations, and the four bulk populations as well as the check cultivar Entsar1 (Table 6). The mean sum of squares due to advanced breeding lines showed significant differences for all studied characteristics at $1 \%$ significance level, except shelling percentage which showed significance at $5 \%$ level. So these findings indicate the ample scope of selecting promising lines from the present gene pool for yield and its components. Significant differences were observed between the examined material by the researchers Dursun (2007) on bean, Ron et al (2005), Ceyhan et al (2008), Tan et al (2012) and Rashwan and El-Shaieny (2016) on pea.

Table 6. Mean squares of studied traits for selected lines of pea

\begin{tabular}{|c|c|c|}
\hline Studied traits & $\begin{array}{c}\text { Mean squares } \\
\text { due to geno- } \\
\text { types } \\
\mathrm{df}=24 \\
\end{array}$ & $F$ value \\
\hline Plant length (cm) & 3597.19 & $21.44^{\star *}$ \\
\hline No. of branches/plant & 8.86 & $10.54^{\star \star}$ \\
\hline No. of days to flowering & 133.66 & $78.78^{* *}$ \\
\hline No. of first flowering node & 6.99 & $3.78^{* *}$ \\
\hline Pod length $(\mathrm{cm})$ & 36.57 & $54.37^{\star *}$ \\
\hline Pod width (cm) & 0.24 & $14.72^{\star *}$ \\
\hline Pod thickness (cm) & 0.06 & $6.58^{* *}$ \\
\hline Pod weight (g) & 53.30 & $25.69^{\star *}$ \\
\hline No. of seeds/pod & 10.75 & $5.97^{\star *}$ \\
\hline Weight of seeds/pod (g) & 8.12 & $11.54^{\star *}$ \\
\hline No. of pods/plant & 697.26 & $13.33^{* *}$ \\
\hline Weight of 100 seeds $(\mathrm{g})$ & 966.76 & $10.26^{\star *}$ \\
\hline Shelling percentage (\%) & 390.75 & $1.76^{\star}$ \\
\hline Pod yield/plant (g) & 30487.14 & $12.35^{\star *}$ \\
\hline Seed yield/ plant (g) & 6290.23 & $11.21^{* *}$ \\
\hline
\end{tabular}

\section{Mean performance of selected lines}

\section{Growth characters}

Data in Table (7) showed that the selected K1 line gave the highest average of plant length $(72.13 \mathrm{~cm})$ but the least average of plant length $(40.87 \mathrm{~cm})$ was conferred by check cultivar. Among all the tested genotypes, the selected G1 line exhibited the highest value for No. of branches per plant (2.96) followed by check cultivar (1.72) while the least No. of branches per plant was found in bulk populations KB and NB (1.09). As shown in Table (7), the performance of selected line growth 
Table 7. Mean performance for different characteristics of selected lines of pea

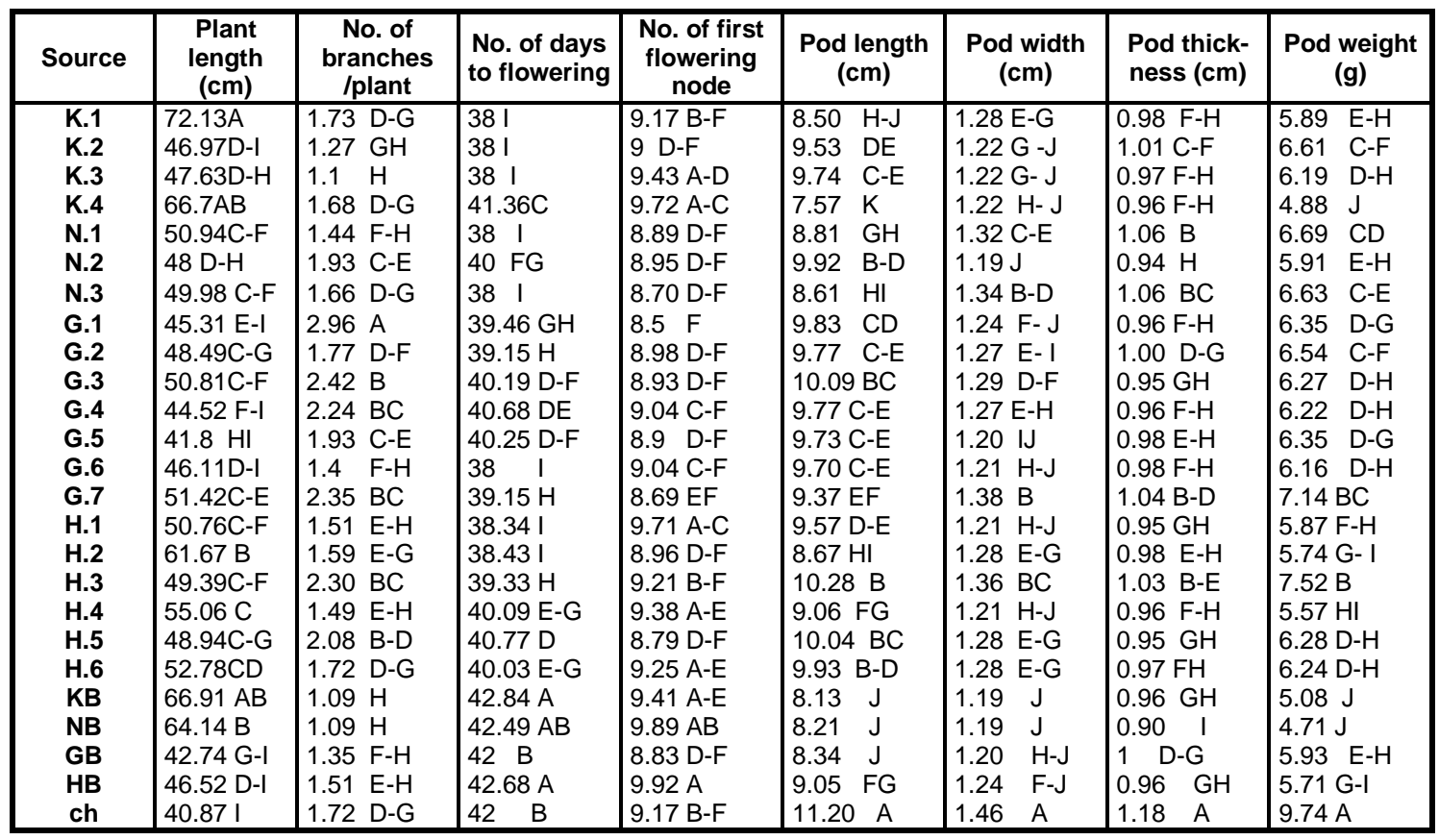

Table 7. Cont.

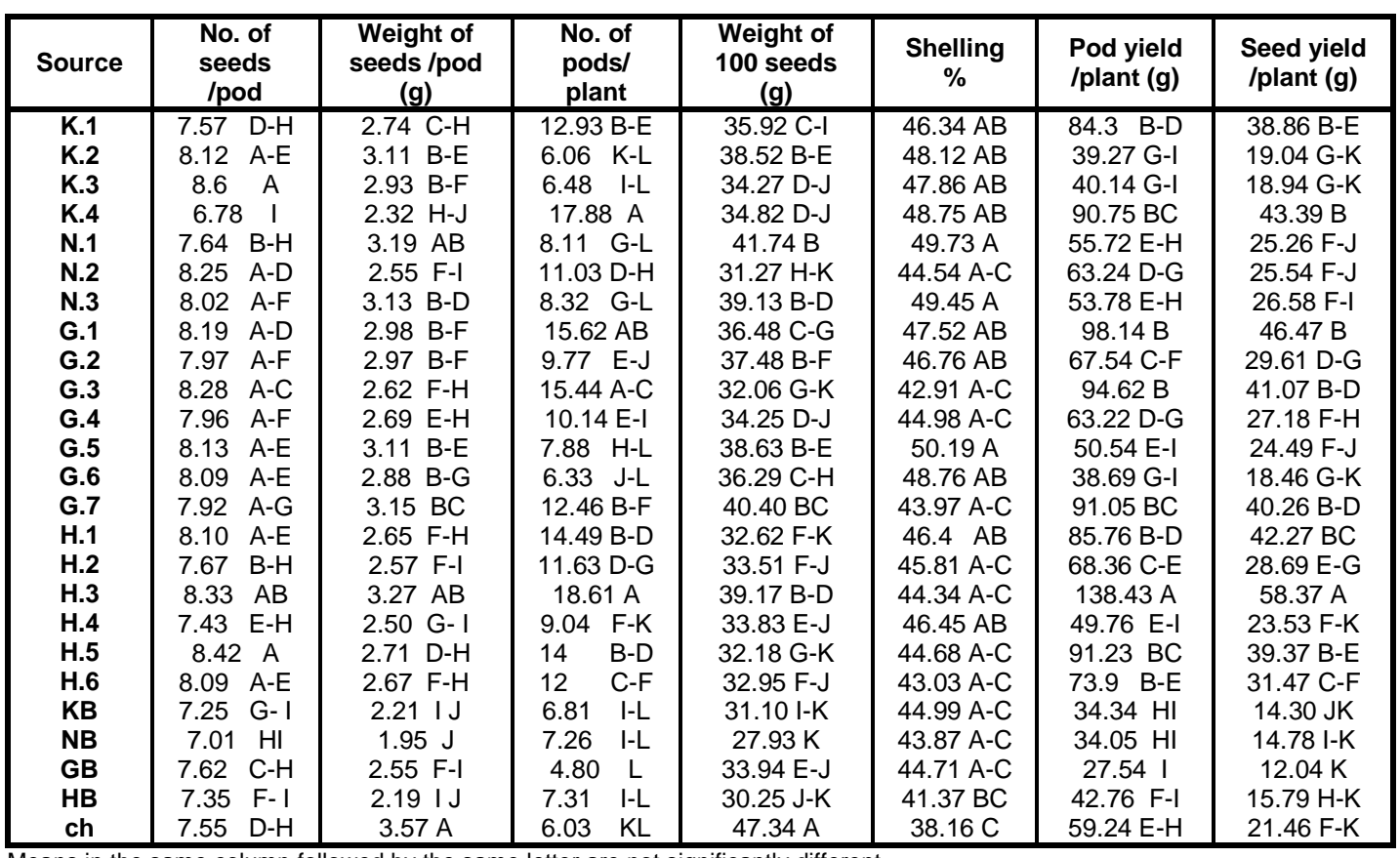




\section{Master B Cultivar}

characteristics compared to bulk populations and check cultivar proved that the twenty selected lines showed less requirements of No. of days to flowering significantly comparing with the bulk populations and the check cultivar. The required days to flowering ranged between $\mathbf{4 1 . 3 6}$ days in $\mathbf{K} 4$ line to 38 days in $\mathbf{K} 2$ line, while ranged between 42.84 to 42 days in bulk populations of $\mathbf{K B}$ and $\mathbf{G B}$, respectively and 42 days in check cultivar. The G1 line gave the least average of No. of first flowering node (8.50) but the highest average of first flowering node (9.92) was obtained in bulk population HB. While check cultivar bears the first flower at average node number of 9.17 .

\section{Yield and its components}

Data in Table (7) showed significant variation in pod length between the tested genotypes. Thence, the longest pod $(11.20 \mathrm{~cm})$ was obtained by check cultivar followed by the $\mathrm{H} 3$ line $(10.28$ $\mathrm{cm})$ while K4 line gave the shortest pod $(7.57 \mathrm{~cm})$. Check cultivar gave the highest average of pod width $(1.46 \mathrm{~cm})$ followed by selected $\mathrm{G} 7$ line (1.38 $\mathrm{cm})$ while the lowest significant average of pod width $(1.19 \mathrm{~cm})$ was recorded by KB, N2 and NB genotypes. Check cultivar gave the highest average of pod thickness $(1.18 \mathrm{~cm})$ followed by the $\mathbf{N} \mathbf{1}$ line $(1.06 \mathrm{~cm})$, while the bulk population NB gave the lowest significant pod thickness $(0.90 \mathrm{~cm})$. The significant highest value of pod weight among all tested genotypes was recorded by check cultivar $(9.74 \mathrm{~g})$ followed by H3 line (7.52 g) while NB population showed significant least value of pod weight $(4.71 \mathrm{~g})$. Data in Table (7) showed that the significant highest value of No. of seeds per pod was conferred by $\mathrm{K} 3$ line ( 8.60 seeds), while the significant lowest value was exhibited by $\mathbf{K} 4$ line (6.78 seeds) compared to check cultivar which recorded average 7.55 seeds per pod. As for weight of seeds per pod, the significant heaviest seeds per pod were borne by check cultivar (3.57 $\mathrm{g})$, H3 line (3.27 g) and $\mathbf{N} 1$ line $(3.19 \mathrm{~g})$, and the differences between them was not significant. While the lighter seeds per pod were achieved by the NB (1.95 g), HB (2.19 g), KB (2.21 g) and K4 $(2.32 \mathrm{~g})$ genotypes, and the differences between them was not significant. The highest significant value of No. of pods per plant was exhibited by H3 line (18.61) and K4 line (17.88). Meanwhile, the least significant value of pod number per plant was exhibited by GB line (4.80) but the median pod number per plant (6.03) was recorded by check cultivar. As for weight of 100 seeds, the highest significant value was obtained by check cultivar $(47.34 \mathrm{~g})$ followed by the $\mathbf{N} 1$ line $(41.74 \mathrm{~g})$ while, the NB bulk population gave the lowest significant value $(27.93 \mathrm{~g})$ of weight of 100 seeds. As for shelling percentage, G5 line exhibited the highest significant percent $(50.19 \%)$ while the check cultivar gave the lowest significant percent $(38.16 \%)$ of this character.

Concerning pod yield per plant, data in Table (7) showed that H3 line recorded the highest significant value of pod yield per plant $(138.43 \mathrm{~g})$ but GB bulk population recorded the lowest significant value (27.54 g.) while check cultivar (59.24 g.) located immediately before GB population. With regard to seed yield per plant, data in Table (7) showed that $\mathbf{H 3}$ line recorded the highest significant value of seed yield per plant $(58.37 \mathrm{~g})$ while the lowest significant values were obtained by GB population (12.04 g) and check cultivar $(21.46 \mathrm{~g})$.

Data could be summarized that the studied characters exhibited heritability rate ranged from medium to high for two consecutive cycles of selection. This implies that these characteristics are stable in facing the environmental changes except shelling percentage which was greater influenced by the environment. The characteristics of days to $50 \%$ flowering and days to first harvest exhibited heritability of medium to high level, indicating that selection in segregating generation could be effective for evolving early maturing genotypes (Sharma and Sharma, 2012).

In order to determine which selected lines are suitable for commercial vegetable production as promising cultivar or as parents for further breeding programs, the scoring points were used and each studied characters was given a score from 1 to 5 , except pod yield per plant and seed yield per plant that were given a score from 1 to 10 , thence these traits are considered the main target of agriculture production. Flowering and yielding characteristics as No. of days to flowering and No. of first flowering node along with green pod characteristics as pod length, pod width, pod thickness, pod weight, No. of seeds per pod and weight of seeds per pod were more preferable characteristics that should be improved in the new cultivar. Therefore, earliness yielding along with better green pod characteristics are considered the main demands for producer and consumer. The evaluation of these lines for further breeding programs adopted the sum total of all studied characters, thence greater emphasis should be given to all characteristics for yield improvement through breeding programs. Ron et al (2005) used pod characteristics to indi- 
cate the quality for fresh pod production and use nine significant quantitative attributes for global quality including earliness. Depending on the results of scoring points for studied genotypes as shown in Table (8), all selected lines showed superiority compared to the baseline sources for all the traits, generally, which underlines the importance of the selection in improving the qualities of cultivars. Some of selected lines outperformed in total score of the traits comparing with the check cultivar as presented. The selected genotypes H3, G7, N1, N3, G2, G1 and K2 may be considered as promising cultivars because they have good pod characteristics with higher productivity and earliness in flowering. While, the rest of selected genotypes (K1, K3, K4, N2, G3, G4, G5, G6, H1, H2, H4, H5 and H6) could be used for improving characteristics of yield and its contributing traits through breeding programs.

Another goals were achieved under the present study, i.e. evaluation of different materials to obtain lines with high yielding along with earliness and identifying superior lines for breeding programs beside improve some studied characters using typical or some different breeding procedures. These results are fairly consistent with those of Dursun (2007) on bean, Deshpand et al (2010) on cowpea, Nosser (2011) on broad bean, Ron et al (2005), Ceyhan et al (2008), Tan et al (2012), Bhnan (2013) and Rashwan and El-Shaieny (2016) on pea.

\section{Correlation among studied traits}

Correlation coefficients of studied traits for all tested genotypes are shown in Table (9). At the beginning, it could be emphasized that pea yield consists mainly of pod yield per plant, pod number per plant, seed number per pod, seed yield per plant and average seed weight. Otherwise, the highest correlation coefficient value was recorded between pod yield per plant and pod number per plant as well as seed number per pod, seed number per plant and average seed weight as found by Krarup and Davis (1970). The results of correlation between pea traits will be processed through many ways as follows:

1- Correlations between pod yield components and plant vegetative growth, i.e. plant length and branch number per plant: both of the two traits have higher heritability through two selection cycles indicating to the presence of additive gene effect. So that these traits can be improved directly through selection procedure depending on morphological variation. These traits was positively correlated with pod number per plant trait so selection for improving pod number traits indirectly improve both of plant length and branch number. Otherwise, plant length trait was negatively correlated with seed number and weight per pod but branch number trait was positively correlated with seed number and weight per pod. Georgieva et al (2016) reported that the negative correlation observed between seed yield and plant height indicates that tall plants supporting many leaves could increase total biomass instead seed weight. Finally, data of correlation between pod yield and its components, and vegetative growth traits especially plant length and number of branches per plant proved that pod yield and its components could be improved by improving number of branches trait more than plant length. Positive correlation between seed yield and No. of primary branches per plant was recorded by Rasaei et al (2011), Singh et al (2011) and Abdulla et al (2014). The positive correlation was found between No. of seeds per pod and No. of branches per plant by Kosev and Mikić (2012). Also positive correlation between plant height and pods number per plant was found by Sharma et al (2011), Ramzan et al (2014) and Georgieva et al (2015). Green pod yield per plant showed positive and significant correlation with pod length and No. of developed ovules (seeds) per pod but negative and significant correlation with plant height (Singh and Lokendra, 2015).

2- Correlations between pod yield components and flowering traits as number of days to flowering and number of first flowering node: the results revealed that pod and seed yield traits and there components showed negative correlation with flowering traits as number of days to flowering and number of first flowering node. On the other hand, heritability and genetic advance of flowering traits recorded medium to higher rates through two cycles of selection indicating to presence of additive and none additive gene effect. The expected genetic advance of flowering traits (or any trait) depends on genetic variability. When the variability in baseline materials is fewer or absent, selection procedure for improvement is not advisable but it is preferable adopting other procedure as crossing or hybridization to improve flowering traits. Also under the same condition of this study, when the target is to improve flowering traits, it 

Master B Cultivar

Table 8. Scoring for determination of the best lines which can be used as promising cultivar or as parents for breeding programs

\begin{tabular}{|c|c|c|c|c|c|c|c|c|c|}
\hline Source & C3 (5) & C4 (5) & C5 (5) & C6 (5) & C7 (5) & C8 (5) & C9 (5) & C10 (5) & $\begin{array}{c}\text { Total score as } \\
\text { promising } \\
\text { cultivar (40) }\end{array}$ \\
\hline K.1 & 5 & 4.2 & 2.8 & 3.8 & 3.4 & 3.4 & 3.2 & 3.6 & 29.4 \\
K.2 & 5 & 4.6 & 3.8 & 3 & 4 & 4 & 4.2 & 4.2 & 32.8 \\
K.3 & 5 & 3.8 & 4 & 3 & 3.4 & 3.6 & 5 & 4 & 31.8 \\
K.4 & 3.4 & 3.6 & 2.2 & 2.8 & 3.4 & 2.4 & 2.2 & 2.4 & 22.4 \\
N.1 & 5 & 4.6 & 3.2 & 4.2 & 4.8 & 4.4 & 3.6 & 4.8 & 34.6 \\
N.2 & 4.4 & 4.6 & 4.4 & 2.4 & 3 & 3.4 & 4.4 & 2.8 & 29.4 \\
N.3 & 5 & 4.6 & 3 & 4.4 & 4.6 & 4.2 & 4 & 4.4 & 34.2 \\
G.1 & 4.6 & 5 & 4.2 & 3.2 & 3.4 & 3.8 & 4.4 & 4 & 32.6 \\
G.2 & 4.8 & 4.6 & 4 & 3.4 & 3.8 & 4 & 4 & 4 & 32.6 \\
G.3 & 4 & 4.6 & 4.6 & 4 & 3.2 & 3.6 & 4.6 & 3 & 31.6 \\
G.4 & 3.8 & 4.4 & 4 & 3.6 & 3.4 & 3.6 & 4 & 3.2 & 30 \\
G.5 & 4 & 4.6 & 4 & 2.6 & 3.6 & 3.8 & 4.2 & 4.2 & 31 \\
G.6 & 5 & 4.4 & 4 & 2.8 & 3.4 & 3.6 & 4.2 & 3.8 & 31.2 \\
G.7 & 4.8 & 4.8 & 3.6 & 4.8 & 4.4 & 4.6 & 3.8 & 4.6 & 35.4 \\
H.1 & 5 & 3.6 & 3.8 & 2.8 & 3.2 & 3.2 & 4.2 & 3 & 28.8 \\
H.2 & 5 & 4.6 & 3 & 3.8 & 3.6 & 3 & 3.6 & 2.8 & 29.4 \\
H.3 & 4.8 & 4.2 & 4.8 & 4.6 & 4.2 & 4.8 & 4.8 & 4.8 & 37 \\
H.4 & 4.2 & 4 & 3.4 & 2.8 & 3.4 & 2.8 & 3 & 2.6 & 26.2 \\
H.5 & 3.6 & 4.6 & 4.6 & 3.8 & 3.2 & 3.6 & 5 & 3.4 & 31.8 \\
H.6 & 4.2 & 4 & 4.4 & 3.8 & 3.4 & 3.6 & 4.2 & 3 & 30.6 \\
KB & 2.8 & 4 & 2.4 & 2.4 & 3.2 & 2.6 & 2.6 & 2.2 & 22.2 \\
NB & 3 & 3.4 & 2.4 & 2.4 & 2.8 & 2.4 & 2.4 & 2 & 20.8 \\
GB & 3.2 & 4.6 & 2.6 & 2.8 & 3.8 & 3.4 & 3.4 & 2.8 & 26.6 \\
HB & 2.8 & 3.2 & 3.4 & 3.2 & 3.2 & 3 & 2.8 & 2.2 & 23.8 \\
Ch & 3.2 & 4.2 & 5 & 5 & 5 & 5 & 3.2 & 5 & 35.6 \\
\hline
\end{tabular}

Table 8. Cont.

\begin{tabular}{|c|c|c|c|c|c|c|c|c|c|}
\hline Source & C1 (5) & C2 (5) & C11 (5) & C12 (5) & C13 (5) & C14 (10) & C15 (10) & $\begin{array}{l}\text { Total score } \\
\text { as promising } \\
\text { cultivar }(40)\end{array}$ & $\begin{array}{c}\text { Total score } \\
\text { as breeding } \\
\text { lines (85) }\end{array}$ \\
\hline K.1 & 5 & 2.8 & 4.2 & 3.4 & 4.8 & 8.8 & 8.4 & 29.4 & 66.8 \\
\hline K.2 & 3.2 & 2 & 2 & 4.2 & 4.8 & 5.6 & 5.2 & 32.8 & 59.8 \\
\hline K.3 & 3.4 & 1.8 & 2.2 & 3.2 & 4.8 & 5.6 & 5.2 & 31.8 & 58 \\
\hline K.4 & 4.8 & 2.8 & 5 & 3.2 & 4.8 & 9.2 & 9.6 & 22.4 & 61.8 \\
\hline N.1 & 3.8 & 2.2 & 2.6 & 4.8 & 5 & 6.8 & 6 & 34.6 & 65.8 \\
\hline N.2 & 3.4 & 3.2 & 3.4 & 2.2 & 4.6 & 7.2 & 6 & 29.4 & 59.4 \\
\hline N.3 & 3.8 & 2.8 & 2.6 & 4.4 & 5 & 6.8 & 6.4 & 34.2 & 66 \\
\hline G.1 & 3 & 5 & 4.8 & 3.8 & 4.8 & 9.6 & 9.6 & 32.6 & 73.2 \\
\hline G.2 & 3.6 & 3 & 3 & 4 & 4.8 & 7.6 & 7.6 & 32.6 & 66.2 \\
\hline G.3 & 3.8 & 3.8 & 4.6 & 2.4 & 4.6 & 9.6 & 8.8 & 31.6 & 69.2 \\
\hline G.4 & 2.8 & 3.6 & 3.2 & 3.2 & 4.6 & 7.2 & 6.8 & 30 & 61.4 \\
\hline G.5 & 2.4 & 3.2 & 2.4 & 4.2 & 5 & 6.4 & 6 & 31 & 60.6 \\
\hline G.6 & 3.2 & 2.2 & 2.2 & 3.6 & 4.8 & 5.6 & 5.2 & 31.2 & 58 \\
\hline G.7 & 4 & 3.6 & 4 & 4.6 & 4.6 & 9.2 & 8.8 & 35.4 & 74.2 \\
\hline H.1 & 3.8 & 2.4 & 4.4 & 2.6 & 4.8 & 8.8 & 9.2 & 28.8 & 64.8 \\
\hline H.2 & 4.6 & 2.6 & 3.6 & 2.8 & 4.6 & 8 & 7.2 & 29.4 & 62.8 \\
\hline H.3 & 3.8 & 3.6 & 5 & 4.4 & 4.6 & 10 & 10 & 37 & 78.4 \\
\hline H.4 & 4.4 & 2.4 & 2.8 & 3 & 4.8 & 6.4 & 5.6 & 26.2 & 55.6 \\
\hline H.5 & 3.6 & 3.4 & 4.4 & 2.4 & 4.6 & 9.2 & 8.4 & 31.8 & 67.8 \\
\hline H. 6 & 4.2 & 2.8 & 3.8 & 2.8 & 4.6 & 8.4 & 8 & 30.6 & 65.2 \\
\hline KB & 4.8 & 1.8 & 2.2 & 2 & 4.6 & 5.2 & 4 & 22.2 & 46.8 \\
\hline NB & 4.6 & 1.8 & 2.2 & 1.8 & 4.6 & 5.2 & 4.4 & 20.8 & 45.4 \\
\hline GB & 2.6 & 2.2 & 1.8 & 3 & 4.6 & 4.8 & 3.8 & 26.6 & 49.4 \\
\hline $\mathrm{HB}$ & 3.2 & 2.4 & 2.2 & 2 & 4.4 & 6 & 4.8 & 23.8 & 48.8 \\
\hline ch & 2.2 & 2.8 & 2 & 5 & 4.2 & 6.8 & 5.6 & 35.6 & 64.2 \\
\hline
\end{tabular}

K1-K2-K3-K4-N1-N2-N3-G1-G2-G3-G4-G5-G6-G7-H1-H2-H3-H4-H5-H6: The selected lines.

$\mathrm{C} 3=$ No. of days to flowering. $\mathrm{C} 4=$ No. of first flowering node. $\mathrm{C} 5=$ pod length. $\mathrm{C} 6=$ pod width

$\mathrm{C} 7=$ pod thickness. $\quad \mathrm{C} 8=$ pod weight. $\quad$ C9=No. of seeds/pod. C $10=$ weight of seeds $/$ pod.

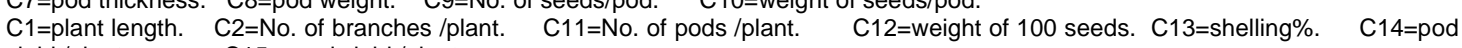
yield/plant. 
is preferable to study flowering and yielding traits each in separate work. Earliness of flowering through this work is easily improved despite the negative correlation with yielding traits, this is due to the less variability in earliness of flowering between baseline populations. Therefore, earliness of flowering trait, which Master B cultivar is featured, has been purified.

Basaiwala et al (2013) found that the negative correlation of seed yield with days to $50 \%$ flowering (express on earliness). Ramzan et al (2014) reported that days to $50 \%$ flowering had positive and significant correlation with No. of pods per plant, on the other hand it was negatively and significantly correlated with pod length and No. of seeds per pod. Kumar et al (2015) found that the node at which the first flower appears (number) had a positive correlation with days to first flower, plant height and negatively associated with No. of pods per plant.

3- Higher heritability (through two selection cycles) of pod number per plant, pod length, pod width and seed number and weight per pod as well as positive correlation between these traits with pod and seed yield traits prove the presence of additive gene effect and adoption selection procedure for improving these traits and subsequently improving pod and seed yield traits. Otherwise, selection for higher pod and seed yield traits mean indirect selection for improving traits of pod number per plant, pod length, pod width and seed number and weight per pod. Strongest positive correlation between seed yield and No. of pods per plant was detected by Tyagi and Srivastava (2002), Singh and Singh (2006), Togay et al (2008), Rasaei et al (2011), Singh et al (2011), Tyagi et al (2012), Basaiwala et al (2013), Kumar et al (2013a) and Siddika et al (2013). Also, strongest positive correlation between pod yield and No. of pods per plant was detected by Chaudhary and Sharma (2003), Sharma et al (2011), Kumari et al (2008), Kumar et al (2015), Tofiq et al (2015) and Katoch et al (2016). Positive correlation of seed yield with pod length and pod width was found by Siddika et al (2013) and lqbal et al (2015). Positive correlation of seed yield with seeds per pod was reported by Tyagi and Srivastava (2002), Singh and Singh (2006), Rasaei et al (2011), Basaiwala et al (2013), Kumar et al (2013a) and Siddika et al (2013). Positive correlation between pod yield and pod length was observed by Kumar et al (2015), Singh and Lokendra (2015) and Katoch et al (2016).

Relationship between pod length and pod width was significant and positive correlation (Avci and Ceyhan, 2006). There were highly significant positive correlation between pod length with weight of seeds per pod and 100 seed weight (Tofiq et al 2015). Pod length was positively and significantly correlated with number of seeds per pod during both the seasons (Katoch et al 2016).

\section{CONCLUSION}

Pea genotype characteristics used in this study showed moderate to high GCV along with moderate to high heritability which gave a good chance for improving these characteristics through selection procedure. Higher estimate of heritability in broad sense for studied traits with moderate to high GCV after two cycles of selection gives ample scope for further improvement especially for No. of pods per plant, pod yield and the seed yield and the results of the correlation analysis will be the best guide for this aim. This work presents the selected genotypes H3, G7, N1, N3, G2, G1 and K2 as promising lines could be handled as cultivars because they have good pod characteristics with higher productivity and earliness in flowering. Also presents the rest of the selected genotypes $\mathrm{K} 1$, K3, K4, N2, G3, G4, G5, G6, H1, H2, H4, H5 and $\mathrm{H} 6$ that could be used for improving yield and its attributing traits through future breeding programs.

\section{REFERENCES}

Abdulla, A.R., Ahmed, J.O. and Ahmed, S.A. 2014. Study five genotypes of pea (Pisum sativum L.) in terms of yield and yield components under conditions Sulaymanyah - Bakrajo. International Journal of Engineering and Technical Research (IJETR) 2 (3),18 -22.

Ajmal, S.U., Zakir, N. and Mujahid, M.Y. 2009. Estimation of genetic parameters and character association in wheat. J Agric. Biol. Sci. 1, 1518.

Allard, R.W. 1960. Principles of Plant Breeding. John Willey and Sons, New York. 485pp.

Amin, A., Mushtaq, F., Singh, P.K., Wani, K.P., Spaldon S. and Nazir N. 2010. Genetics and breeding of pea-a review. Intl. J. Curr. Res. 10, 28-34. 
Avci, A.M. and Ceyhan E. 2006. Correlations and genetic analysis of pod characteristics in pea (Pisum sativum L.). Asian J. Plant Sci. 5(1), 14.

Basaiwala, P., Rastog N.K. and Parikh M. 2013. Genetic variability and characteristics association in field pea (Pisum sativum L.) genotypes. Asian J. Hort. 8(1), 288-291.

Bhnan, E.Y. 2013. New developed lines of pea via pedigree selection. Egypt. J. Plant Breed. 17(1), 19-31.

Bozokalfa, M.K., Yağmur B., Aşçıoğul T.K. and Eşiyok D. 2011. Diversity in nutritional composition of Swiss chard (Beta vulgaris subsp. L. var. cicla) accessions revealed by multivariate analysis. Plant Genet Resources 9, 557-566.

Burton, G.W. and DeVane E.H. 1953. Estimating heritability in Tall Fescue (Festuca arundinacea) from replicated clonal material. Agron. J. 45, 481-487.

Ceyhan, E., Avci, M.A. and Karadas, S. 2008. Line $X$ tester analysis in pea (Pisum sativum L.): Identification of superior parents for seed yield and its components. African Journal of Biotechnology 7(16), 2810-2817.

Chadha, S., Sharma, R., Chaudhary, D.R. and Vidyasagar 2008. Genetic variability studies in summer pea under cold desert areas of NorthWestern Himalayas. Agric. Sci. Digest. 28(1), $10-13$.

Chakraborty, R. and Chakraborty, S. 2010. Genetic variability and correlation of some morphometric traits with grain yield in bold grained rice (Oryza sativa L.) gene pool of Barak valley. American-Eurasian Journal of Sustainable Agriculture, 4(1), 26- 29.

Chaudhary, D.K. and Sharma, R.R. 2003. Genetic variability, correlation and path analysis for green pod yield and its components in garden pea. Indian J. Hort. 60(3), 251-256.

Deshpand, K.S., Patil, B.R., Salimath, P.M. Nidagundi, J.M. and Karthigeyan, S. 2010. Evaluation of native and collected germplasm for earliness seed traits and resistance to rust, CMV and leaf spot in cowpea [Vigna unguiculata (L.) Walp]. Electronic Journal of Plant Breeding 1(4), 384- 392.

Dostálová, R., Seidenglanz, M. and Griga, M. 2005. Simulation and assessment of possible environmental risks associated with release of genetically modified Peas (Pisum sativum L.) into environment in Central Europe. Czech J. Genet. Plant Breed. 41 (2), 51- 63.
Duncan, D.B. 1955. Multiple range and multiple $F$ test. Biometrics 11, 1-42.

Dursun, A. 2007. Variability, heritability and correlation studies in bean (phaseolus vulgaris L.) genotypes. World J. Agric. Sci., 3(1), 12-16.

Esiyok, D., Bozokalfa, M.K. and Ascıogul, T.K. 2011. Variability, heritability and association analysis in plant traits of swiss chard (Beta vulgaris subsp. cicla), Genetika, 43(2), 239-252.

Georgieva, N., Nikolova, I. and Kosev, V. 2015. Association study of yield and its components in pea (Pisum sativum L.). International Journal of Pharmacognosy (IJP) 2 (11), 536-542.

Georgieva, N., Nikolova, I. and Kosev, V. 2016. Evaluation of genetic divergence and heritability in pea (Pisum sativum L.). J. BioSci. Biotechnol. 5(1), 61-67.

Gupta, A.J., Singh, Y.V. and Verma, T.S. 2006. Genetic variability and heritability in garden pea (Pisum sativum L.). Indian J. Hort. 63(3), 332334.

Habtamu, S. and Million, F. 2013. Multivariate analysis of some Ethiopian field pea (Pisum sativum L.) genotypes. Int. J. Genet. Mol. Biol. 5(6), 78-87.

Hamed, A.A. 2012. Selection for some economic characteristicss in two populations of pea. Egypt. J. of Appl. Sci., 27(7), 362-377.

Iqbal, M., Bashir, I., Iqbal, M., Nadeem, K., Lateef, A., Chishti, S.A.S. and Niaz, S. 2015. Association pattern among yield and its related attributes in peas (Pisum sativum L.). J. Agric. Res. 53(2), 173-177.

Johnson, H.W., Robinson, H.F. and Comstock, R.E. 1955. Estimates of genetic and environmental variability in soybeans. Agron. J. 47, 314-318.

Katoch, V., Singh, P., Devi, M.B., Sharma, A., Sharma, G.D. and Sharma, J.K. 2016. Study of genetic variability, characteristics association, path analysis and selection parameters for heterotic recombinant inbred lines of garden peas (Pisum sativum var. hortense L.) under mid-hill conditions of Himachal Pradesh, India. Legume Research, 39(2),163-169.

Kosev, V. and Mikić, A. 2012. Short communication. Assessing relationships between seed yield components in spring-sown field pea ( $\mathrm{Pi}$ sum sativum L.) cultivars in Bulgaria by correlation and path analysis. Span. J Agric. Res. 10(4), 1075-1080.

Krarup, A. and Davis, D.W. 1970. Inheritance of seed yield and its components in a six parent 
diallel cross in peas. J. Amer. Soc. Hort. Sci. (95), 795-797.

Kumar, B., Kumar, A., Singh, A.K. and Lavanya, G.R. 2013a. Selection strategy for seed yield and maturity in field pea (Pisum sativum L. arvense). Afr. J. Agric. Res. 8(44), 5411-5415.

Kumar, D., Malik, S., Singh, S.K. and Kumar, M. 2013b. Genetic variability, heritability and genetic advance for seed yield and yield components in garden pea (Pisum sativum L.). India, Vegetos 26 (1), 182-184.

Kumar, R., Kumar, M., Dogra, R.K. and Bharat, N.K. 2015. Variability and characteristics association studies in garden pea (Pisum sativum var. hortense L.) during winter season at mid hills of Himachal Pradesh. Legume Research 38(2), 164-168.

Kumari, A., Kumar, M. and Kohli, U.K. 2008. Genetic parameters and characteristics association in garden pea (Pisum sativum L.) Cultivars. Veg. Sci. 35(2), 160-164.

Kumari, N., Srivastava, J.P., Singh, S.K. and Singh, I.P. 2012. Heritability and genetic advance in vegetable pea (Pisum sativum L.). Ann. Agric. Res. New Series 33 (4), 244-246.

Mohan, N., Aghora, T.S., Wani, M.A. and Divya, B. 2013. Garden pea improvement in India. J. Hortl. Sci. 8(2), 125-164.

Monti, L.M. 1983. Natural and induced variability in peas for protein production. In Perspective for Peas and Lupins as Protein Crops (ed. Thompson and Carsey). World Crops 8, 2329.

Nosser, M.A. 2011. Development of some new broad bean (Vicia faba L.) lines by selection. J. Plant Production, Mansoura Univ. 2(11), 1481-1494.

Pal, A.K. and Singh S. 2013. Assessment and genetic variability in garden pea (Pisum Sativum L. var. hortense). Int. J. agric. Sci. 9 (1), 293-296.

Pandey, P., Singh, N. and Rawat, M. 2015. Study of genetic variation, heritability and correlation in vegetable pea (Pisum sativum L.). The Bioscan 10 (4), 2131-2133.

Ramzan, A., Noor, T., Khan, T.N. and Hina, A. 2014. Correlation, cluster and regression analysis of seed yield and its contributing traits in pea (Pisum sativum L.). J. Agric. Res. 52(4), 481- 488.

Rasaei, A., Ghobadi, M.E., Ghobadi, M. and Abdi-niya, K. 2011. The study of traits correlation and path analysis of the grain yield of the peas in semi-dry conditions in Kermanshah. Interna- tional Conference on Food Engineering and Biotechnology (IPCBEE) 9, 246-249.

Rashwan, A.M.A. and El-Shaieny, A.H.A.H. 2016. Pedigree selection in pea (Pisum sativum L.). International Journal of Advanced Research 4(7), 1366-1371.

Ron, D.M.A., Magallanes, J.J., Martinez, O., Rodino, P. and Santalla, M. 2005. Identifying superior snow pea lines. Hort. Science 40(5), 1216-1220.

SAS, 2006. Statistical Analysis System, SAS User's Guide: Statistics, SAS Institute Inc. Editors, Cary, NC.

Saxesena, R.R., Vidyakar, V., Vishwakarma M.K., Yadav, P.S., Meena, M.L. and Lal, G.M. 2014. Genetic variability and heritability analysis for some quantitative traits in field pea ( $P i$ sum sativum L.). The Bioscan 9(2), 895-898.

Sendecor, G.W. and Cochran, W.G. 1982. Statistical Methods. $\left(7^{\text {th }}\right.$ ed. $2^{\text {nd }}$ Printing). The lowa State, University Press, Ames, lowa, U.S.A.

Sharma, B.B. and Sharma, V.K. 2012. Genetic analysis for earliness and yield traits in garden pea (Pisum sativum L.). India, Vegetos 25(1), 63-67.

Sharma, M.K., Chandel, A. and Kohli, U.K. 2011. Genetic evaluation correlation coefficients and path analysis in garden pea (Pisum sativam var. hortense L.). Prog. Agric. 11(2), 434-439.

Sharma, V.K. and Bora, L. 2013. Studies on genetic variability and heterosis in vegetable pea (Pisum sativum L.) under high hills condition of Uttarakhand, India. Afr. J. Agric. Res., 8(18), 1891-1895.

Siddika, A., Islam, A.K.M.A., Rasul, M.G., Mian, M.A.K. and Ahmed, J.U. 2013. Genetic variability in advanced generation of vegetable pea (Pisum sativum L.). International Journal of Plant Breeding 7(2), 124-128.

Singh, A., Singh, S. and Babu, J.D.P. 2011. Heritability, characteristics association and path analysis studies in early segregating population of field pea (Pisum sativum L. var. arvense). Int. J. Plant Breed. Genet, 5(1), 86-92.

Singh, J.D. and Singh, I.P. 2006. Genetic variability, heritability, expected genetic advance and characteristics association in field pea (Pisum sativum L.). Legume Res., 29(1), 65 - 67.

Singh, K.P. and Lokendra, S. 2015. Selection parameters for green pod yield and its component in table pea (Pisum sativum L.). Annals of Horticulture Abst. 8(2), 173-176. 
Singh, R.K. and Chaudhary B.D., 1985. Biometrical Methods in Quantitve Genetic Analysis. Kalyani publishers, Ludhiana, New Dlhi. India, 318 p.

Singh, U.P., Ganesh, M. and Srivastava, C.P. 1997. Detection of epistasis and estimation of components of genetic variation applying modified triple test cross analysis using two testers in pea (Pisum sativum L.). Ind. J. Genet. PI. Breed. 57,138-142.

Tan, M., Koc, A. and Gul, Z.D. 2012. Morphological characteristics and seed yield of east anatolian local forage pea (Pisum sativum ssp. arvense L.) ecotypes. Turkish Journal of Field Crops 17(1), 24-30.

Tofiq, S.E., Abdulkhaleq D.A., Amin T.N.H. and Azez O.K. 2015. Correlation and path coefficient analysis in seven field pea (Pisum sativum L.) genotypes created by half diallel anal- ysis in sulaimani region for $F_{2}$ generation. International Journal of Plant, Animal and Environmental Sciences, 5(4), 93- 97.

Togay, N., Togay, Y., Yildirim, B. and Dogan, Y. 2008. Relationships between yield and some yield components in Pea (Pisum sativum ssp arvense L.) genotypes by using correlation and path analysis. Afr. J. Biotechnol. 7(23), 42854287.

Tyagi, M.K. and Srivastava, C.P. 2002. Genetic variability and correlations among yield and yield characters over two environments in Pea. Indian J. Agric. Res. 36 (1), 53 - 56.

Tyagi, N., Singh, A.K., Rai, V.P., Kumar, S. and Srivastava, C.P. 2012. Genetic variability studies for lodging resistance and yield attributes in pea (Pisum sativum L.). Journal of Food Legumes 25(3), 179-182. 